\title{
Reconstrucción de la articulación temporomandibular (ATM): prótesis aloplástica
}

\author{
Reconstruction of the temporomandibular joint (TMJ): alloplastic prostheses
}

\author{
C. Goizueta Adame
}

Resumen: La incapacidad de desarrollar sistemas inertes eficaces para la sustitución completa de la articulación temporo-mandibular durante décadas ha generado una variedad de soluciones biológicas para un problema biomecánico. Los injertos autólogos no ofrecen garantías en funcionalidad, simetría, o estabilidad oclusal; resultan técnicamente más complejos y tienen mayor potencial morbilidad. El paciente candidato a reconstrucción completa de la ATM debe contar con la posibilidad de una prótesis si otras opciones fracasan. La reconstrucción aloplástica garantiza estabilidad oclusal, técnica sencilla y reproducible, estancia hospitalaria predecible y baja tasa de complicaciones con los sistemas protésicos actuales. Siempre van a existir pacientes en los que ésta sea la única opción, por lo tanto es primordial la medición de la magnitud de las fuerzas implicadas en la mecánica de la ATM para poder diseñar prótesis en base a modelos fiables como en otras articulaciones en las que ya han resuelto el problema.

Palabras clave: Prótesis de ATM; Reconstrucción temporomandibular aloplástica; Reconstrucción temporomandibular autóloga.

Recibido: 05-11-2004

Aceptado: 18-11-2004
Abstract: Incapabability to develop effective inert systems to total temporomandibular joint substitution during decades has genered several biologic solutions for a biomecanic question. Autologous grafts don't offer security in functioning, simmetry, or oclusal estability; its have more coplex technique and more potencial morbility. Alloplastic reconstruction guarantees oclusal stability, single and reproducible technique, predictable time in hospital, and low morbility with actual prosthetic systems. Patients whos prostheses is only one option are going to exist always, so that it is primordial measures of magnitude of implicated strenghts in TMJ mecanic to can design prosthesis based on reliable models like others articulations which have just resolved the question.

Key words: TMJ prostheses; Alloplastic temporomandibular reconstruction; Autologous temporomandibular reconstruction.
Médico Adjunto

Servicio de Cirugía Oral y Maxilofacial.

Hospital Universitario de San Juan, Alicante, España

Correspondencia:

c/ Tridente 4, bgw 5

Cabo Huertas, 03540

Alicante, España

goizu15@hotmail.com 


\section{Introducción}

La particulación de los materiales empleados en los sistemas protésicos durante las pasadas décadas, así como su desgaste excesivo o las reacciones a cuerpo extraño, ${ }^{1-3}$ junto con una filosofía agresiva en el tratamiento quirúrgico de la articulación temporo-mandibular (ATM) han provocado el desarrollo de técnicas de autoinjerto (costocondral, esterno-clavicular, metatarso-falangeal, peroné) $)^{4-7}$ para la sustitución articular como en ninguna otra articulación de la anatomía. De hecho, no existen apenas autoinjertos en las articulaciones periféricas para la reconstrucción articular completa. El uso de tejido autólogo proporciona una funcionalidad aceptable sin necesidad de recurrir a materiales aloplásticos dado el reducido tamaño a rehabilitar. Intraoperatoriamente puede fijarse de forma segura como una prótesis quedando sujeto a la rama remanente por tornillos, placas o alambres y es adaptable al lecho y a la anatomía del caso, pudiendo requerir bloqueo intermaxilar (BIM) para asegurar la estabilidad. Se puede completar la técnica con un revestimiento de tejido blando (dérmico, fascial, fasciomuscular, etc.) para la fosa glenoidea. Es una opción establecida y ampliamente aceptada en la

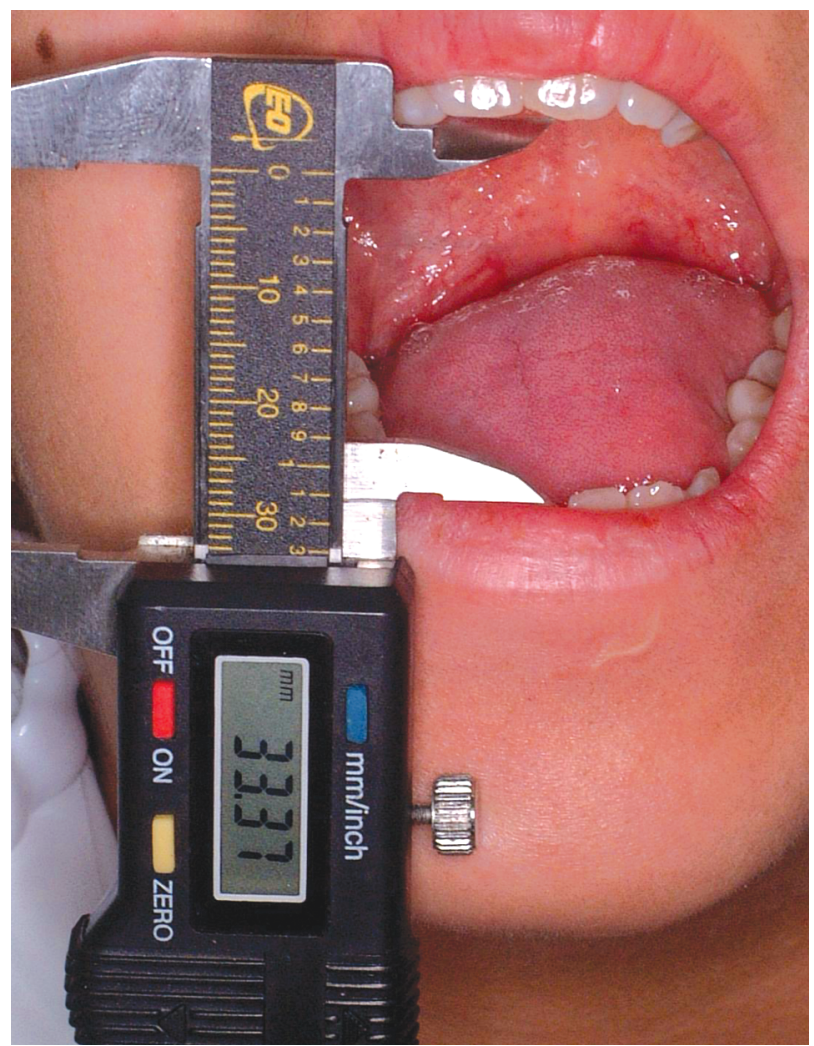

Figura 1. Anquilosis post-traumática a los 4 años por fractura de cóndilo derecho intervenida con 12 años mediante injerto costocondral. Apertura pre-quirúrgica $8 \mathrm{~mm}$. La imagen es del $18^{\circ}$ mes postoperatorio.

Figure 1. Post-traumatic ankylosis at the age of 4 due to a fractured right condyle, operated on at the age of 12 with a costochondral graft. Pre-surgical aperture of $8 \mathrm{~mm}$. Image taken 18 months after surgery. literatura para reconstrucción de la ATM en anquilosis, 8,9 disfunción/OA, oncología, traumatología y en general se ha utilizado en deformidad articular severa de cualquier origen. ${ }^{10}$ El más usado y más comunicado es el injerto costocondral.

Pero estos injertos pueden fallar, por reabsorción, por crecimiento excesivo, ${ }^{11}$ o por anquilosis, creando mordida abierta , disoclusión o limitación severa del movimiento.4,12 Si algo de esto ocurre es necesario contar con un sistema aloplástico capaz de rescatar estos fracasos o solventar aquellos en los que el autoinjerto se desestima como primera opción. Por lo tanto, parece que no existe tal controversia, a cada uno lo suyo. El principal problema que presenta la sustitución completa con sistema protésico en la ATM es que va a haber que cambiarlo, como en cualquier otra articulación.

\section{Indicaciones}

En edad de crecimiento no existen dudas sobre la opción mejor (Fig. 1). En general se obtienen excelentes resultados con los injertos autólogos que se van a adaptar a los cambios del paciente y permiten realizar tratamientos combinados con ortopedia/ortodoncia, cirugía ortognática o distracción ósea.

\section{Introduction}

The particularization of the materials used in prosthesis systems during the past decades, the excessive wear or foreign body reactions, ${ }^{1-3}$ together with an aggressive philosophy with regard to the surgical treatment of the temporomandibular joint (TMJ), has led to the development of autograft techniques (costochondral, sternoclavicular, metatarsal-phalangeal, fibular) $)^{4-7}$ for substituting this joint more than any other joint in the anatomy. There are in fact practically no autografts in the peripheral joints that can be used for total joint reconstruction.

The use of autologous tissue achieves a functional outcome that is acceptable without the need to resort to alloplastic material, given the limited size of the area to be reconstructed.

It can be firmly fixed intraoperatively as if it were a prosthesis, given that it is secured to the remaining ramus with screws, plates or wires, and it can be adapted to the bed and to the case anatomy. Intermaxillary fixation (IMF) may be required to ensure stability. The technique can be completed by using a covering of soft tissue (dermis, fascia, or muscular-fascia, etc.) for the glenoid pit. This is an established and widely accepted option in the literature8,9 for reconstructing the TMJ in ankylosis, AO dysfunction, oncology, traumatology, and in general it has been used for severe joint deformity of any origin. 10 The graft that has been most used and reported is the costochondral graft.

But these grafts can fail, because of resorption or excessive growth, ${ }^{11}$ or because of ankylosis, leading to an open bite, malocclusion or severe limitation of movements. ${ }^{12,4}$ If any of this occurs, we need to be able to rely on an alloplastic system that is capable of correcting a failure, or that can resolve if an autograft has been rejected as a first option. Therefore there is apparently no such controversy, each to his own. With regard to total TMJ replacement by means of a prosthetic device, the principal problem faced is that, as with any other joint, this will have to be replaced. 
En la edad adulta existen factores que van a influir en la indicación de una u otra opción como la edad, el origen del problema, el tiempo de evolución y los tratamientos previos, sobre todo si fueron quirúrgicos.

La colocación de un injerto supone dos riesgos fundamentales:

- La aceptación e integración del tejido transplantado implica la posibilidad de recidiva de la enfermedad originaria, bien por su origen (neoplásico, sistémico, autoinmune o metabólico), o bien por falta de control de los factores etiológicos (aplanamiento, o erosión similar a osteoartrosis) e incluso anquilosis.

- La no aceptación e integración del tejido transplantado provocará reabsorción, disoclusión paulatina, alteración musculoesquelética.

La reconstrucción con sistemas aloplásticos elimina en parte estas posibilidades. El resultado depende de la correcta integración del material de fijación, de las superficies de contacto de las fases del sistema y de la correcta técnica quirúrgica.

En opinión del autor la reconstrucción protésica es la primera opción en: 1. Articulación con enfermedad metabólica o autoinmune (Fig. 2).

2. Neoplasia articular primaria o metastásica.

3. Fracaso de autoinjerto previo.

4. Articulación con anquilosis de larga evolución y puede serlo también en:

- Articulación desestructurada con cirugías previas (en especial si alguna de éstas ha actuado sobre el cóndilo).

- Artropatía degenerativa severa (Figs. 3 y 4 ).

Estos supuestos, salvo en el caso de neoplasia por motivos obvios, deberán presentar un severo problema mecánico o doloroso o ambos, con o sin maloclusión asociada, que deberá intentarse corregir en un solo acto.

\section{Técnica quirúrgica}

En reconstrucción completa de la ATM los objetivos intraoperatorios

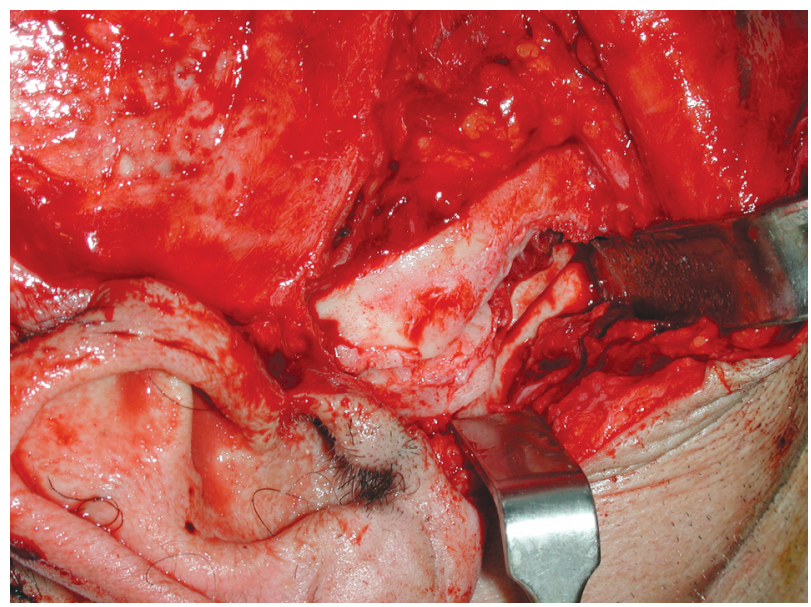

Figura 2. Anquilosis ósea verdadera en un paciente de 70 años. Enfermedad de Paget que afecta a la hemimandíbula derecha. Inmovilidad completa prequirúrgica de 5 años de evolución.

Figure 2. Rue bony ankylosis in a 70-year-old patient. Paget's disease affecting the right half of the mandible that had for five years been completely immobile.

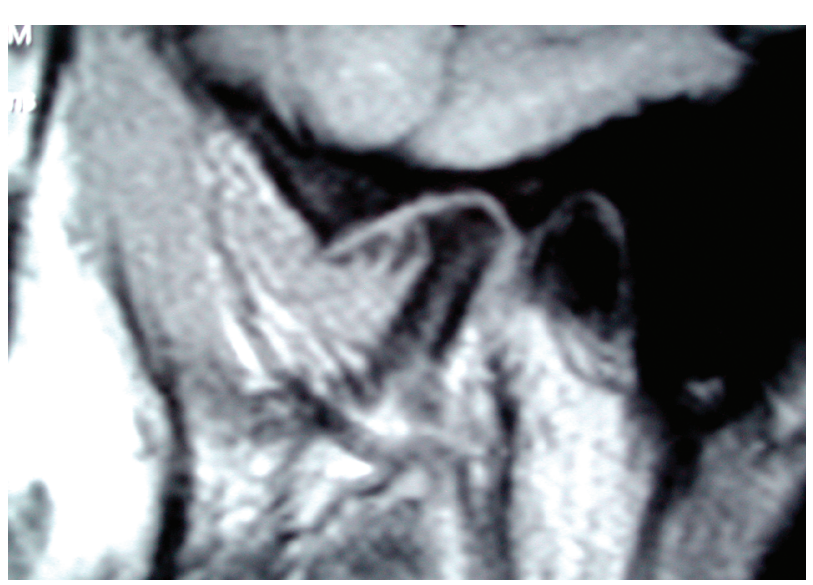

Figura 3. RM que muestra una osteoartrosis severa en un paciente de 50 años con gran sintomatología dolorosa e impotencia funcional en el lado izquierdo.

Figure 3. MR showing severe osteoarthrosis in a 50-year-old patient with considerable symptoms of pain and functional loss on left side.

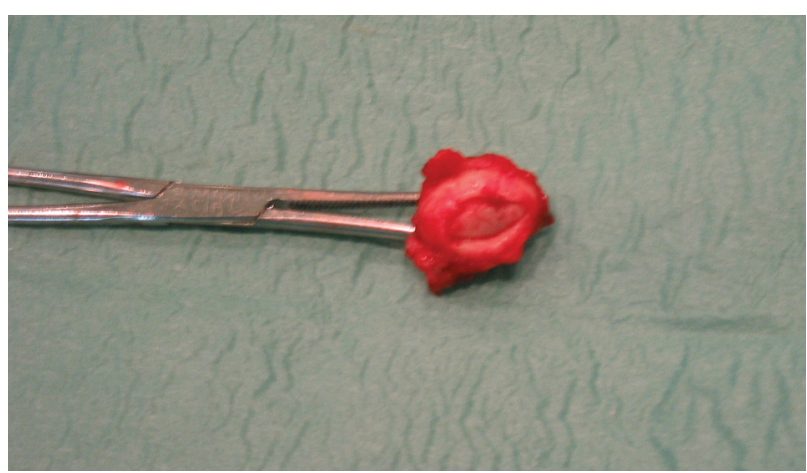

Figura 4. Pieza quirúrgica correspondiente a la paciente de la imagen anterior que muestra una gran perforación del disco con severa deformidad condilar.

Figure 4. Surgical specimen from the patient in the previous image showing considerable disc perforation with severe condylar deformity.

\section{Indications}

During the growing years there is no doubt as to the best option (Fig. 1). In general excellent results are obtained with autologous grafts as they adapt to changes within the patient, and they can be combined with orthopedic/orthodontic or distraction treatment. For adults there are certain factors that can influence the indications for one or another option such as age, origin of the problem, time evolved, and previous treatment, especially if surgical.

The placement of a graft involves two fundamental risks:

- The acceptance and integration of the transplanted tissue implies the possibility of the original disease recurring, either because of its origin (neoplastic, systemic, autoimmune or metabolic), or because of a lack of control of the etiological factors (a leveling or erosion similar to osteoarthrosis) and even ankylosis. - The non-acceptance and nonintegration of the transplanted material will lead to resorption, gradual malocclusion and musculoskeletal changes.

Reconstruction with alloplastic systems eliminates to some extent these possibilities. The result depends on the correct integration of the fixation material and contact surfaces in the phases of the system, and on a correct surgical technique.

In the opinion of the author, prosthetic reconstruction is the first option for:

1. Joints with a metabolic or autoimmune disease (Fig. 2). 2. Joints with primary or metastasic neoplasia.

3. Previous autograft failures. 4. Long-term ankylosed joints. It can also be for: 
deben ser equiparables sin importar el uso de material autólogo o aloplástico, por tanto comparten técnica.

Una vez resecado el fragmento mandibular y liberado el techo cigomático-temporal de restos de tejido articular, tejido fibroso o cicatricial o restos óseos y comprobada la adecuada movilidad de la mandíbula, se introduce la reconstrucción por la incisión cervical o retromandibular:

\section{Autoinjerto}

- Va a precisar de un revestimiento de tejido blando en el techo de la neo articulación (aconsejable un colgajo fascio o fasciomuscular), o de una terminación cartilaginosa del neo cóndilo (costo-condral, ester-

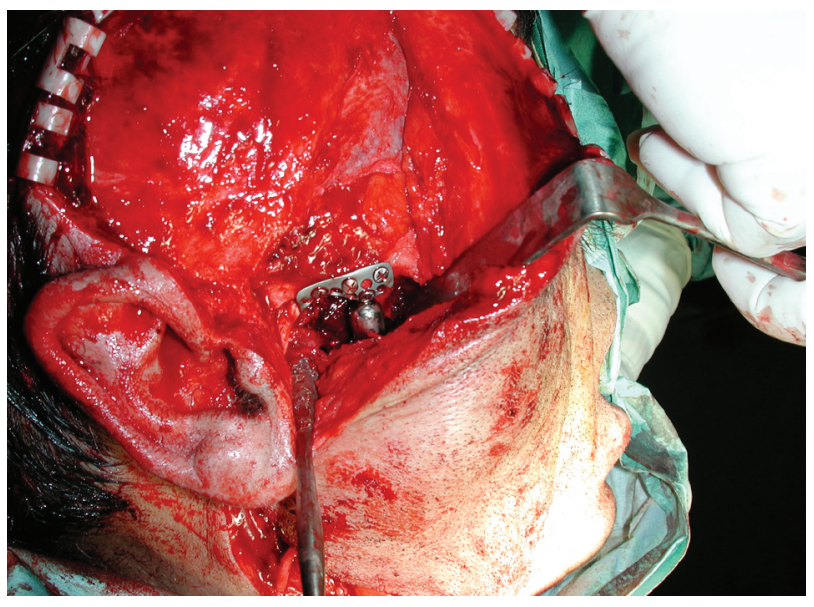

Figura 5. Sistema Christensen colocado en el paciente de la figura 2 tras la resección del bloque anquilótico con la apófisis coronoides y tallado de neofosa, fase condilar en máxima apertura. Figure 5. Christensen system placed in the patient in Figure 2 following resection of the ankylotic segment with the coronoid process and contouring of the new fossa, condylar position at maximum aperture.
- Joints with damaged structures due to previous surgery (especially if on the condyle). - Severe degenerative arthropathy (Figs. 3 and 4). In these cases (except for obvious reasons in neoplasia cases) there should be a severe mechanical problem or pain or both, with or without associated malocclusion, which should be corrected in a single act.

\section{Surgical technique}

For the total reconstruction of the TMJ the intraoperative objectives should be comparable, regardless of the use of autologous or alloplastic material, and the same technique is therefore used.

Once the mandibular fragment has been resected and the zygomatic-temporal vault freed from joint tissue, fibrous or scar tissue, or from any bone remains, and once the mandible has been checked for suitable mobility, the reconstruction is introduced through a cervical or retromandibular incision. cirujano y de las condiciones intraoperatorias.

- El bloqueo intermaxilar postquirúrgico puede ser necesario e incluso imprescindible.

- Existen dos campos quirúrgicos y dos zonas anatómicas a vigilar en el postoperatorio.

\section{Prótesis}

Actualmente se comercializan en España dos sistemas protésicos para la reconstrucción completa de ATM

- El sistema Christensen (TMJ Implants, Inc, Golden, CO) se utiliza desde la década de los sesenta y no ha sufrido modificaciones importantes en su diseño (Fig. 5). El diseño de la prótesis de fosa-eminencia está basado en 44 muestras de cadáver para cada lado, viene perforada en su cornisa externa y se fija con tornillos al arco cigomático. Sobre esta fosa de cobaltocromo (Co-Cr) se enfrenta una cabeza de la misma aleación, con un armazón (Co-Cr) que se fija a la cara externa de la rama mediante tornillos del mismo material. También puede colocarse con una prolongación sobre el cuerpo mandibular para casos con falta de apoyo. Es posible encargarlo a medida con una reconstrucción esterolitográfica. Se utiliza como hemiartroplastia (sin la parte condilar), ${ }^{13}$ aunque es un tratamiento discutido por otros autores. ${ }^{14}$ Es la prótesis más utilizada en EE.UU. y está avalada por numerosas publicaciones. Sus resultados son predecibles y la técnica resulta sencilla según en qué caso.

\section{Autograft}

- A soft tissue covering will be needed in the vault of the new joint (a fascia or muscular-fascia flap is advisable), or a cartilaginous finish for the new condyle (costochondral, sternoclavicular), or both.

- Adaptation can require the modification of both structures - mandibular ramus and graft-giving attention to possible weakening, loss of continuity or fracture of the graft.

- The fixation system (plates, screws and wires) is not preestablished, and to a large extent it will depend or the criteria of the surgeon and of the intraoperative conditions.

- Postsurgical intermaxillary fixation can be necessary and even indispensable.

- There are two surgical fields and two anatomical areas to supervise during the postoperative [period].

\section{Prosthesis}

Currently there are two prosthesis systems marketed in Spain for total reconstruction of the TMI. 
- El sistema Lorenz (W.Lorenz) es una prótesis de stock, modifica el diseño de la parte craneal descendiendo el eje de rotación, lo que provoca una prótesis de fosa eminencia gruesa en sentido vertical, fabricada en polietileno de ultraalto peso molecular (UHMWPE) que se fija con tornillos al arco cigomático, se presenta en tres tamaños y permite ser cementada con PMMA para mejorar la estabilidad. El componente condilar está fabricado en cobalto-cromo, la superficie de contacto con el hueso huésped está cubierta de plasma de titanio rugoso. El diseño implica la resección de la parte más craneal de la rama mandibular. Este diseño se basa en la literatura de ortopedia enfrentando polietileno (componente fosa-eminencia) contra metal (componente mandibular) y en las innovaciones de diseño de Falkestrom y Van Loon, 15, 16 para aumentar el efecto de traslación (Figs. 6 y 7).

Los resultados publicados desde 1995 refieren de 30 a $34 \mathrm{~mm}$ como objetivo alcanzable. Se encuentra aún en fase de estudio pero está consentido su uso.

\section{Rehabilitación}

Existen tres causas que provocan la

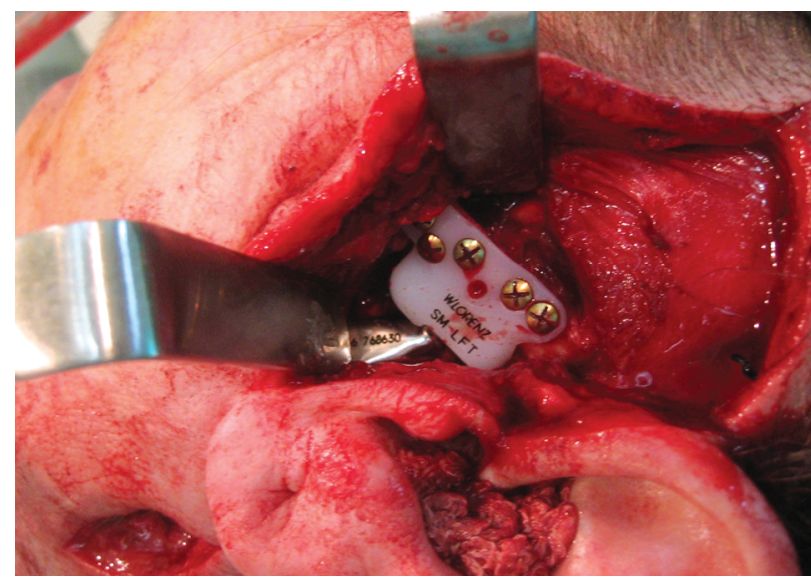

Figura 6. Sistema Lorenz usado en la paciente de las figuras 3 y 4. Figure 6. Lorenz system used in the patients in Figures 3 and 4.

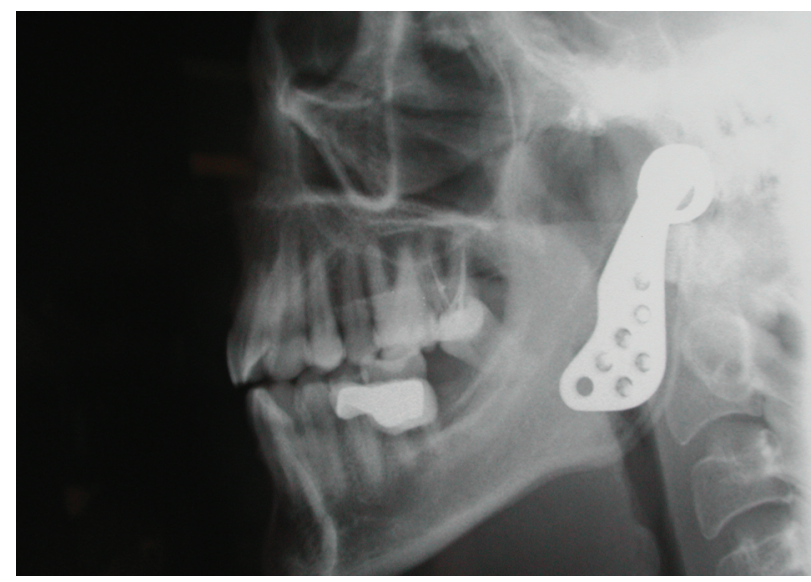

Figura 7. Imagen radiológica postoperatoria del caso anterior Obsérvese la resección de la apófisis coronoides, escotadura y borde posterior de la rama mandibular en una sola línea de corte. Figure 7. Postoperative $X$-ray of previous case. Note the resection of the coronoid process, notch and posterior border of the mandibular ramus along a single incision line. restricción del movimiento articular: los

tejidos intra y periarticulares, el espasmo muscular y la fibrosis cicatricial que presentan muchos de estos pacientes. La cirugía ortopédica en traumatología hace ya décadas que estableció la ventaja de movilizar la musculatura que sostiene la articulación tratada de forma precoz. ${ }^{17}$ En el uso del autoinjerto la dependencia del metabolismo del paciente (neovascularización y formación de callo e integración del tejido apuesto), supone un plazo de inmovilización consciente o forzada (BIM) de por lo menos tres semanas. Se está inmovilizando un aparato musculoesquelético que está afectado desde hace un largo período de tiempo y al que se ha sometido a una agresión quirúrgica, en muchos casos con componente cicatricial previo. Los rangos de movimiento definitivos de estos pacientes no van a establecerse hasta pasado un año. ${ }^{18}$

Con el sistema protésico la rehabilitación va a comenzar en la primera semana postquirúrgica, el paciente va a poder mover la musculatura desde los primeros días y no existen curas de la zona donante; la incorporación del paciente a su actividad diaria es mas temprana.
- The Christensen system (TMJ Implants, Inc., Golden CO) has been used since the 70s, and no significant modifications have been made to its design (Fig. 5). The design of the fossa-eminence prosthesis is based on 44 cadaver models for each side. It has a perforated flange and it is secured with screws to the zygomatic arch. On this cobalt chrome (Co-Cr) fossa a head of the same alloy is placed, with a (Co-Cr) shell that is secured to the outer surface of the ramus with screws of the same material. It can also be placed on the mandibular body using a flange in cases where there is little support. It can be made to measure with stereolithographic reconstruction. It can be used as hemi-arthroplasty (without the condylar part),13 although other authors have disputed this treatment. ${ }^{14}$ This prosthesis is the most used in the US and it has been endorsed by numerous publications. The results are predictable and, depending on the case, the technique is simple. - The Lorenz system (W. Lorenz) is a stock prosthesis with a modified design of the cranial area. It has a lower center of rotation, which results in a prosthesis with a wide fossa-eminence with regard to the vertical position. It is made with ultra-high molecular weight polyethylene (UHMWPE) that is secured with screws to the zygomatic arch. It comes in three sizes and it can be cemented with PMMA in order to improve stability. The condylar component is made with chrome-cobalt and the area where there is contact with the host bone is coated with rough titanium-plasma. The design requires the resection of the most cranial part of the mandibular ramus. This design is based on the orthopedic literature that places polyethylene (the fossa eminence component) with metal (the mandibular component) and on Falkestrom and Van Loon's design innovations ${ }^{15,16}$ for increasing the translatory effect (Figs. 6 and 7).

- The results published from 1995 onwards indicate that 30 to $34 \mathrm{mms}$ should be the objective to reach. It is still in a study phase, but its use has been approved. 


\section{Discusión}

La cirugía reconstructiva de la ATM tiene como objetivos fundamentales: 1. Restaurar en la medida de lo posible la funcionalidad mandibular.

2. Disminuir la sintomatología dolorosa.

3. Evitar la perpetuación de los tratamientos.

4. Evitar las recidivas del problema en el mayor espacio de tiempo o de forma definitiva.

5. Contener los costes de la terapia tanto para el paciente como para el asegurador.

La reconstrucción con prótesis cumple en gran medida con estos objetivos mediante:

1. Técnica sencilla (para el cirujano familiarizado con la región anatómica y los sistemas de osteosíntesis), de tiempo quirúrgico conocido, estancia hospitalaria predecible y morbilidad asociada reducida (Fig. 8).

2. Estabilidad oclusal y estabilidad de la dimensión vertical. El injerto autólogo tiene un comportamiento impredecible, puede quedar estable, pero puede reabsorbers e, puede sobrecrecer o incluso puede crear anquilosis.

3. Rehabilitación más precoz y mas segura sin precisar de BIM.

Sin embargo, presenta inconvenientes como:

- Ausencia de componente traslacional en el movimiento de la mandíbula y, por lo tanto, resultado pobre en máxima apertura oral.

No existe una reconstrucción que restaure todos los movimientos articulares, con ambas opciones vamos a tener una restricción en el movimiento de traslación. Si se sitúa la cabeza de la reconstrucción en el centro de la fosa anatómica, esta rotará en el movimiento de apertura aunque intentemos fijar los músculos pterigoideos a la cabeza de la reconstrucción (dos milímetros de traslación lateral en manos de Wolford, ${ }^{19}$ tres $\mathrm{mm}$ y medio en la serie de Collins). ${ }^{20}$ Si el injerto funciona bien es de esperar obtener un rango de apertura satisfactorio, aunque una reciente serie con injerto costocondral de 76 articulaciones en 57 pacientes, ${ }^{4}$ refiere la media de aumento de apertura interincisal de 21 a $24 \mathrm{~mm}$, y un movimiento de traslación nulo. El descenso del eje de rotación en los nuevos diseños de sistemas artificiales, ${ }^{15}$ está consiguiendo un efecto de pseudotraslación que mejora en 8 ó $10 \mathrm{mms}$ la apertura interincisal. Es un buen resultado obtener $25 \mathrm{~mm}$ con un sistema protésico que se limite a permitir rotar la mandíbula, el resto del movimiento en la ATM original se debe a la traslación del cóndilo sobre el disco y la eminencia por efecto de los músculos pterigoideos. La pérdida de inserción de éstos, como se señaló arriba, limita el resultado mecánico. Si la rotación en lugar de situar su eje en la cabeza del cóndilo lo desciende hasta el cuello, el arco de rotación será mayor y por tanto se mejorará la apertura.

\section{Rehabilitation}

There are three causes leading to a limitation of joint movement: intra and periarticular tissue, muscular spasms and fibrous scarring, that many of these patients present. Orthopedic surgery for traumatology established decades ago ${ }^{17}$ the advantages of early mobilization of the muscles that support a treated joint. With autografts the reliance on the patient's metabolism (neovascularization, callus formation and good tissue integration), entails a period of conscious or forced immobilization (IMF) of at least three weeks. The musculoskeletal apparatus that has been afflicted for a long time and subjected to a surgical aggression, often having a previous cicatricial process, is immobilized. The definitive movement range of these patients will not be established until a year later. ${ }^{18}$

With prosthetic systems rehabilitation will commence during the first week postsurgery. The patient will be able to move the musculature from the first days and no donor area treatment; the patient is able to go back to his daily activities earlier.

\section{Discussion}

Reconstructive surgery of the TMJ has two fundamental objectives:

1. Restoring as far as possible mandibular function.

2. Reducing the symptoms of pain.

3. Avoiding the perpetuation of treatment.

4. Avoiding recurrence of the problem for as long as possible or definitively.

5. Containing the therapy costs for the patient as well as for the insurer.

Reconstruction with a prosthetic device meets these objectives as:

1. The technique is simple (for the surgeon that is familiar with the anatomical region and osteosynthesis systems), the surgical time is known, the hospital stay is predictable and there is lower associated morbidity (Fig. 8).

2. There is occlusal stability and vertical dimension stability. The behavior of the autologous graft is unpredictable. 
- Déficit en el conocimiento de la magnitud de las fuerzas implicadas en los ciclos, y por tanto diseños prueba-error.

Tras más de ochenta años de estudio, ${ }^{21}$ tenemos una buena comprensión de la biomecánica articular pero las magnitudes de las fuerzas implicadas en la ATM no han sido establecidas, ni en condiciones normales ni en condiciones patológicas. ${ }^{22,}{ }^{23}$ La dificultad en la medición de estas magnitudes ha motivado la incapacidad de desarrollar sistemas inertes capaces de sustituir la ATM de forma eficaz como en la cadera o la rodilla. Este «retraso» que aún padecemos junto con la escasa dimensión del área a tratar puede justificar ya de por si el uso de autoinjertos como primera opción para muchos cirujanos.

\section{Conclusiones}

«La reconstrucción aloplástica completa es una solución biomecánica, más que una solución biológica para el tratamiento de la enfermedad articular grave».24 El desarrollo de las técnicas de cultivo celular e ingeniería tisular, 25,26 podrá modificar algunos aspectos de la balanza, pero siempre será necesario contar con un sistema eficaz, seguro, simple y rápido para mejorar la calidad de vida de aquellos pacientes que no puedan beneficiarse de opciones mejores. La controversia posiblemente no esté en usar injerto o usar prótesis ya que las prótesis siempre van a ser necesarias. Las preguntas actuales se centran en qué diseño de prótesis consigue las mejores medidas funcionales, qué materiales tienen mayor resistencia a los ciclos, qué superficies soportan mejor las cargas y sobre todo la cuantificación de éstas. Estas preguntas no van a resolverse hasta que se establezcan modelos biomecánicos fiables, con parámetros de la funcionalidad articular en condiciones normales o patológicas, como existen en la rodilla o en la cadera.

\section{Bibliografía}

1. Kent JN, Block MS, Halpern J, Fontenot M. Update on the Vitek partial and total temporomandibular joint system. J Oral Maxillofac Surg 1993;51:408-15.

2. Bronstein $\mathrm{SL}$, Retained alloplastic temporomandibular joint Disk implants: a retrospective study. Oral Surg Oral Med Oral Pathol 1987;64:135-45.

3. Ta $L$, Phero JC. Clinical evaluation of patientes with temporomandibular joint implants. J Oral Maxillofac Surg 2002;60:1389-9.

4. Saeed NR, Kent JN. A retrospective study of the costochondral graft in TMJ reconstruction. Plast Reconstr Surg 2003;112:31-6.

5. Wolford LM, Cottreell DA, y cols. Sternoclvicular grafts for temporomandibular joint reconstruction. J Oral Maxillofac Surg 1994;52:119-28.

6. Wax MK, Winslow CP, y cols. A retrospective analysis of temporomandibular joint reconstruction with free fibula microvascular flap. J Oral Maxillofac Surg 1999;57:789-98.

7. Landa LE, Gordon C, et al. Evaluation of long-term second metatarsal reconstruction of the temporomandibular joint. J Oral Maxillofac Surg 2003;61:65-71.

8. Lindquist C, Pihakari A. Autogenous costocondrhal grafts in temporomandibular joint arthroplasty. J Maxillofac Surg 1986;14:143-9.

9. Nelson C, Butrtrum J. Costochondral grafts for posttraumatic temporomandibular joint reconstruction: A review of 6 cases. J Oral Maxillofac Surg 1989;47:1030.
It can remain stable but it can also be resorbed. It can grow too much and it can lead to ankylosis.

3. Rehabilitation takes place earlier and is safer, with no IMF being necessary.

However there are inconveniences such as:

- Absence of the translatory factor in the movements of the mandible and, as a result, there is a poor maximum oral aperture.

There is no reconstruction restoring all the articular movements. With both options we will find that translatory movements are restricted. If the reconstruction head is situated in the anatomical center of the fossa, it will rotate during the aperture movement, even if we try to attach the pterygoid muscles to the reconstruction head (two millimeters of lateral movement in Wolford's hands, 193.5 mms in Collins' series) ${ }^{20}$. If the graft works well, a satisfactory aperture range is to be expected, although a recent series with costochondral grafts of 76 joints in 57 patients ${ }^{4}$ reported an average increase in the interincisal opening of 21 to $24 \mathrm{mms}$, and no translatory movement. The inferior positioning of the center of rotation in the new design of artificial systems ${ }^{15}$ is having the effect of a pseudomovement that improves the interincisal opening by 8 to $10 \mathrm{mms}$. Obtaining $25 \mathrm{mms}$ with a prosthetic system is a good result when it only permits the rotation of the mandible, as the remaining movements of the original TMJ are due to the translatory movement of the condyle on the disc and eminence as a result of the effect of the pterygoid muscles. If these are not inserted, as mentioned previously, the mechanical result would be limited. If the center of rotation is not situated on the condylar head, and if it is inferiorly positioned on the neck, the arc of rotation will be greater and aperture will improve.

- Lack of knowledge as to the magnitude of the forces implied in the cycles and, as a result, trial and error designs.

After more than 80 years of studies ${ }^{21}$ we have a proper understanding of articular biomechanics, but the magnitude of the forces related to the TMJ have not been established under normal conditions nor under pathologic conditions. ${ }^{22,23}$ The difficulty in measuring these forces has led to an inability to develop inert systems capable of substituting the TMJ in an efficient manner such as in the hip or knee. This «delay» that we are still experiencing, together with the reduced dimension of the area to be treated, can justify in itself the use of autografts as a first option for many surgeons.

\section{Conclusion}

«A total alloplastic reconstruction is a biomechanical solution more than a biological solution for the treatment of serious articular disease».24 The development of cell cultivation techniques and tissue engineering 25,26 will permit modification of some of the aspects in the balance, but we will always need to rely on a system that is efficient, safe, simple and fast in order to improve the quality of life of those 
10. MacIntosh RB, Henry FA. A spectrum of application of autogenous costocohndral grafts. J Oral Maxillofac Surg 1977;5:257.

11. Guyuron B, Lasa Cl. Unpredictable growth pattern of costocondhral graft. Plast Reconstr Surg 1992;90:880-6.

12. Politis $C$, Fossion $E$, Bossuyt $M$. The use of costochondral grafts in arthroplasty of the temporomandibular joint. J Cranio Max Fac Surg 1987;15:345-54.

13. Park J, Keller EE. Surgical manegement of advanced degenerative arthritis of temporomandibular joint with metal fossa-hemijoint replacement prosthesis: An 8year retrospective pilot study. J Oral Maxillofac Surg 2004;62:320-8.

14. Wolford L. In Reply. (carta). J Oral Maxillofac Surg 2003;11:008.

15. Falkestrom $\mathrm{CH}$. Biomechanical design of total temporomandibular joint replacement (tesis). University of Groningen 1993.

16. Van Loon J-P, Falkestrom CH. The optimal center of rotation for a temporomandibular joint prosthesis: A three-dimensional kinematical study. I Dent Res 1999;78:43-8.

17. Salter RB. Continuous Passive Motion. Baltimore, MD, Williams \& Wilkins, 1993.

18. Maclntosh RB. The use of autogenous tissues for tempormandibular joint reconstruction. J Oral Maxillofac Surg 2000;58:63-9.

19. Wolford LM, Cottrell DA. Temporomandibular joint reconstruction of the complex patient with the Techmedica custom-made total joint prosthesis. J Oral Maxillofac Surg 1994;52:2-10.

20. Collins CP, Wilson KJ. Lateral pterygoid myotomy with reattachment to the condylar neck: an adjunt to restore function after total joint reconstruction. $J$ Craniofac Surg 2002;13:809-15.

21. Gysi A. Studies on the leverage problem of the mandible. Dental Digest 1921;27:74.

22. Throckmorton GS. Temporomandibular joint biomechanics. Oral Maxillofac Surg Clin North Am 2000;12.

23. Mercuri LG. The use of alloplastic prostheses for temporomandibular joint reconstruction. J Oral Maxillofac Surg 2000;58:70-5.

24. Mercuri LG, Wolford LM. Custom CAD/CAM total tempormandibular joint reconstruction system: Preliminary multicenter report. J Oral Maxillofac Surg 1995;53:10615.

25. Abukawa $\mathrm{H}$, Terai $\mathrm{H}$. Formation of a mandibular condyle in vitro by tissue enginee. J Oral Maxillofac Surg 2003;61:94-100.

26. Cancedda R, Dozin B. Tissue engineering and cell therapy of cartilage and bone. Matrix Biol 2003;22:81-91. patients that are not able to benefit from better options. Possibly the controversy is not related to the employment of a graft or a prosthesis, as prostheses are always going to be necessary. Currently what is in question is the type of prosthesis that has the best functional measurements, what materials are more cycle-resistant, what are the best load bearing surfaces and, more especially, the amount. There questions will not be resolved until there are reliable biomechanical models, with articular function parameters under normal or pathological conditions, as exists with the knee or hip. 